\title{
Observation of an Estuarine Turbidity Maximum in the Highly Impacted Capibaribe Estuary, Brazil
}

\author{
Carlos Augusto França Schettini*, Bárbara Pereira Paiva, Rafael de Andrade Lima Batista, José \\ Cavalcante de Oliveira Filho, Eliane Cristina Truccolo
}

\author{
Universidade Federal de Pernambuco \\ (Av. Prof. Moraes Rego, 1235, Cidade Universitária, CEP 50670-901, Recife, PE, Brazil) \\ *Corresponding author: guto.schettini@gmail.com
}

Estuarine turbidity maxima (ETM) are features present in some estuaries where the concentration of suspended particulate matter (SPM) is higher than elsewhere along the fresh-marine water transition in the estuarine domain (POSTMA, 1967; SCHUBEL, 1968; GEYER, 1993; DYER, 1995). The presence of ETM has important ecological implications: since they occur at places where there is an accumulation of organic matter: bacterioplancton and zooplankton dynamics in estuaries is affected by ETM behavior (CRUMP; BAROSS, 1996; MORGAN et al., 1997). ETM are also important in the pollutants dynamics of an estuary, mainly for those that occur adsorbed to fine clayey sediments (BRUNK et al., 1996).

ETM are formed and maintained as the result of complex interactions between river discharge, tidal dynamics and gravitational circulation (DYER, 1988). The concentration of SPM in the ETM varies over time on tidal, sinodical and seasonal time scales (GRABEMANN et al., 1997). ETM have been studied in many estuaries abroad (ALLEN et al., 1980; GELFENBAUM, 1983; UNCLES et al., 1994; WOLANSKI et al., 1995). In some estuaries they are of an ephemeral nature (KISTNER; PETTIGREW, 2001), while in other cases they do not occur at all (SCHETTINI; TOLDO JÚNIOR, 2006; SCHETTINI et al., 2006).

The physics underlying the formation of the ETM has been studied using both analytical and numerical models (GEYER, 1993; JAY; MUSIAK, 1994; BURCHARD; BAUMERT, 1998; YU et al., 2014) in which the effect of gravitational circulation and tidal pumping is of primary importance, with a high degree of interaction between the flow and the bed. Most ETM have been reported in meso or macro-tidal estuaries.

As regards the Brazilian coast, it is not expected to find ETM in the Southeastern and Southern Regions basically because the tidal regime is microtidal. Some papers have http://dx.doi.org/10.1590/S1679-87592016115006402 reported ETM processes in Paranaguá Bay (PR) (e.g., RIBEIRO et al., 2011), although the higher turbidity zone in that estuary is linked rather to re-suspension due to tidal currents (MANTOVANELLI et al., 2004) than to the occurrence of a true ETM. Other studies on SPM in southern Brazilian estuaries have not reported the presence of ETM (SCHETTINI; TOLDO JÚNIOR, 2006; D'AQUINO et al., 2010). On the other hand, meso and macro tides occur on the shores of the Northeastern and Northern Regions, where there would be a greater likelihood of observing ETM. Nevertheless, there are not many studies of the fine sediment dynamics of this area, and the few that are available do not report the presence of ETM. The fine sediment dynamics of the Caravelas estuary, Bahia has been assessed (SCHETTINI; MIRANDA, 2010; SCHETTINI et al., 2013), despite the fact that this estuary presents a very small freshwater inflow, and the major source of sediments is the inner shelf. Such conditions are unfavorable to the formation of ETM. The eastern shores of Pará seem to present favorable conditions for the formation of ETM, and a single survey carried out in the Caeté estuary has shown a feature in the longitudinal distribution of SPM which fits in with what is expected of an ETM (ASP et al., 2012), even though it has not yet been assessed.

A series of surveys has been carried out in the Capibaribe estuary since 2012 to investigate its circulation, fine sediment transport, deposition patterns and recent environmental evolution. The main appeal of and reason for these assessments was the fact that the Capibaribe estuary is a relatively small system $\left(\sim 10 \mathrm{~km}^{2}\right)$ which traverses the Recife Metropolitan Area (Figure 1), one of the most densely populated areas in Brazil. The population around the estuary is of about 3 million of people. For purposes of comparison, Guanabara Bay (RJ) has an area of $\sim 400 \mathrm{~km}^{2}$ and a surrounding population of 8 million of people. The haphazard urbanization and a most 
totally absent waste water treatment results in poor estuarine water quality. The high load of domestic detritus in the estuary is reflected in the high organic matter content of the sediments, which can attain as much as 20\% (OLIVEIRA et al., 2014).

One type of survey undertaken was the longitudinal survey along the estuary using a fast boat, recording hydrographic data at regular intervals of $1 \mathrm{~km}$. These surveys lasted less than one hour each, guaranteeing a synoptic view of the distribution of the variables at a given phase of the tide. Figure 1 shows the location of the sampling stations where vertical profiles of salinity, temperature, turbidity, dissolved oxygen and chlorophyll were recorded with a JFE-Advantech CTD probe, model Rynko Profiler. Turbidity was measured by an optical backscattering sensor (OBS), and converted to mass concentration applying a conversion curve based on in situ measurements and water samplings. The SPM was determined by gravimetric analysis by filtering samples through pre-weighted filters.

This note refers to a survey carried out on October $11^{\text {th }}$, 2013, when an in situ particle size analyzer by Sequoia model LISST-25X was also utilized. This instrument applies a laser diffraction device which allows the measurement of SPM properties such as mean size and volumetric concentration and transmittance. The LISST was used to record data only at $1 \mathrm{~m}$ below the surface to acquire at least 20 readings ( 2 minutes) while the CTD was cast to measure the whole water column. The tide was neap tide, with a range of $1.1 \mathrm{~m}$. The survey was carried out during the flood phase. The river discharge on the survey day was of about $2 \mathrm{~m}^{3} / \mathrm{s}$.

Figure 2 shows the results of the 2013 survey in terms of field distributions of salinity, temperature, SPM, dissolved oxygen saturation and chlorophyll. The salinity (Figure 2a) intrusion reached up to $14 \mathrm{~km}$ from the mouth, considering the value of $0.5 \mathrm{~g} / \mathrm{kg}$ shown as a light blue line. The salinity decreases up estuary, from $\sim 35 \mathrm{~g} / \mathrm{kg}$ at the mouth to zero at $14 \mathrm{~km}$ from the mouth. The horizontal salinity gradient was low in the lower estuary, and increased as the estuary became shallower ( $4 \mathrm{~km}$ from the mouth), being of $3 \mathrm{~g} / \mathrm{kg} / \mathrm{km}$. Temperature (Figure $2 \mathrm{~b}$ ) showed a $2{ }^{\circ} \mathrm{C}$ range, with higher values of $29.5^{\circ} \mathrm{C}$ at $\mathrm{km} 22$, and lower values of $27.5^{\circ} \mathrm{C}$ in the lower estuary in the bottom layer associated with the higher salinities. The SPM concentration (Figure 2c) near the mouth was of about $10 \mathrm{mg} / \mathrm{l}$, with increasing near bottom values up to $30 \mathrm{mg} / \mathrm{l}$ in the lower estuarine stretch. Up estuary the SPM

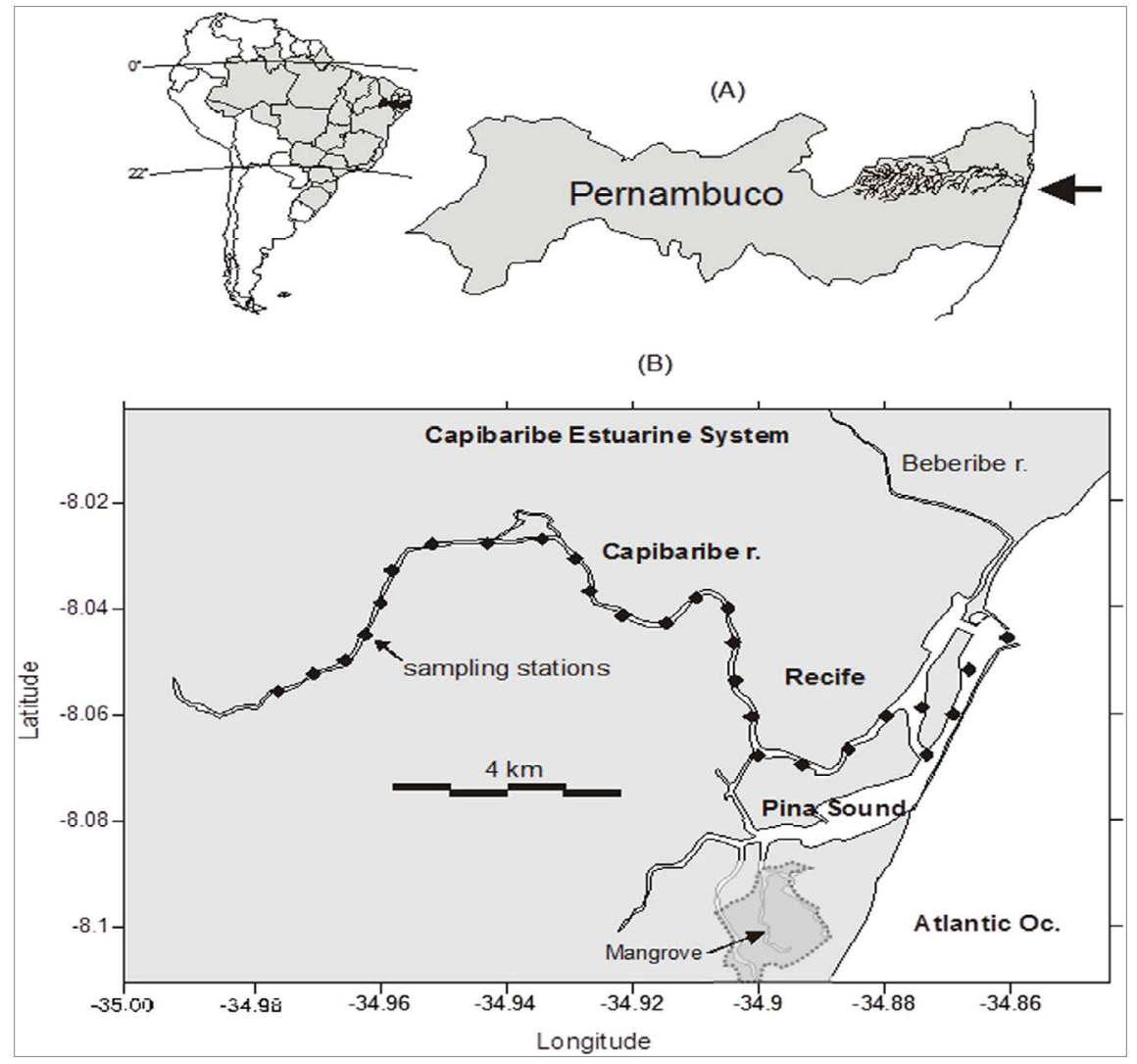

Figure 1. The Capibaribe River estuary, with indication of the sampling stations along the system. 
distribution becomes vertically homogeneous, increasing and reaching its maximum values at $15 \mathrm{~km}$ from the mouth, which coincides with the upper limit of salt intrusion. The dissolved oxygen saturation (Figure 2d) showed higher values in the lower estuary ( $80-90 \%$ ), decreasing up estuary where it decays to $30 \%$, with a thin layer of higher values near the surface. The lower content of oxygen indicates the poor water quality of the estuarine waters, but it is also an indicator of higher residence time. The chlorophyll (Figure 2e) showed lower values $(<5 \mu \mathrm{g} / \mathrm{l})$ near the head and the mouth, and a peak of $60 \mu \mathrm{g} / \mathrm{l}$ at $\mathrm{km} 11$. The maximum chlorophyll occurred in the transition between fluvial and brackish waters, and also reflects the eutrophication of the estuary (e.g. PEREIRA FILHO et al., 2001).

Figure 3 shows the results in terms of longitudinal variation at the surface layer $(0.3-1.3 \mathrm{~m},=11$ readings $)$ for salinity and SPM from the CTD, and at $1 \mathrm{~m}$ below the surface ( $=20$ readings) for volume concentration, particle size and transmittance from LISST. Salinity and SPM varied as described above. The volume concentration (Figure 3c) at the head/mouth is of about $50 \mu 1 / 1$, increasing down/up estuary and reaching the maximum of $180 \mu \mathrm{l} / \mathrm{l}$ at $\mathrm{km} 11$. The particle size (Figure $3 \mathrm{~d}$ ) at the mouth is smaller, $<8 \mu \mathrm{m}$, increasing steeply above $\mathrm{km} 5$ where the largest particles of $\sim 25 \mu \mathrm{m}$ were recorded. Upstream, the mean particle size decreases to nearly $20 \mu \mathrm{m}$, maintaining this value as far as $\mathrm{km} 18$, where it decreases to $\sim 10 \mu \mathrm{m}$. Transmittance (Figure 3e) showed a nearly inverse pattern to that of the SPM, especially in the upper estuary where there is a peak of transmittance associated with a decrease in the SPM. In the lower estuary it was of about $90 \%$, decreasing as far as $\mathrm{km} 11$ where it reached a minimum of $50 \%$, then increasing again up estuary.

The main general conclusion from these observations is the clear presence of an ETM in the Capibaribe estuary, as one expects to find at the transition between brackish and fresh waters. This pattern was confirmed particularly by the data provided by LISST, since the SPM derived from OBS readings showed a second SPM peak at the estuary head. We have other longitudinal profiles available following the same strategy described to record the data presented here, except for the use of the LISST. This instrument has been proven to be very sensitive and difficult to operate. We used it in the present survey as a probe operated from a computer, which means that we calibrated it at every station before sampling data. This creates a logistic problem for the use of a computer in a small open boat, mainly in the lower estuary where conditions are windy and rough. When the LISST is used in its self logging option, it is turned on at the beginning of the survey and

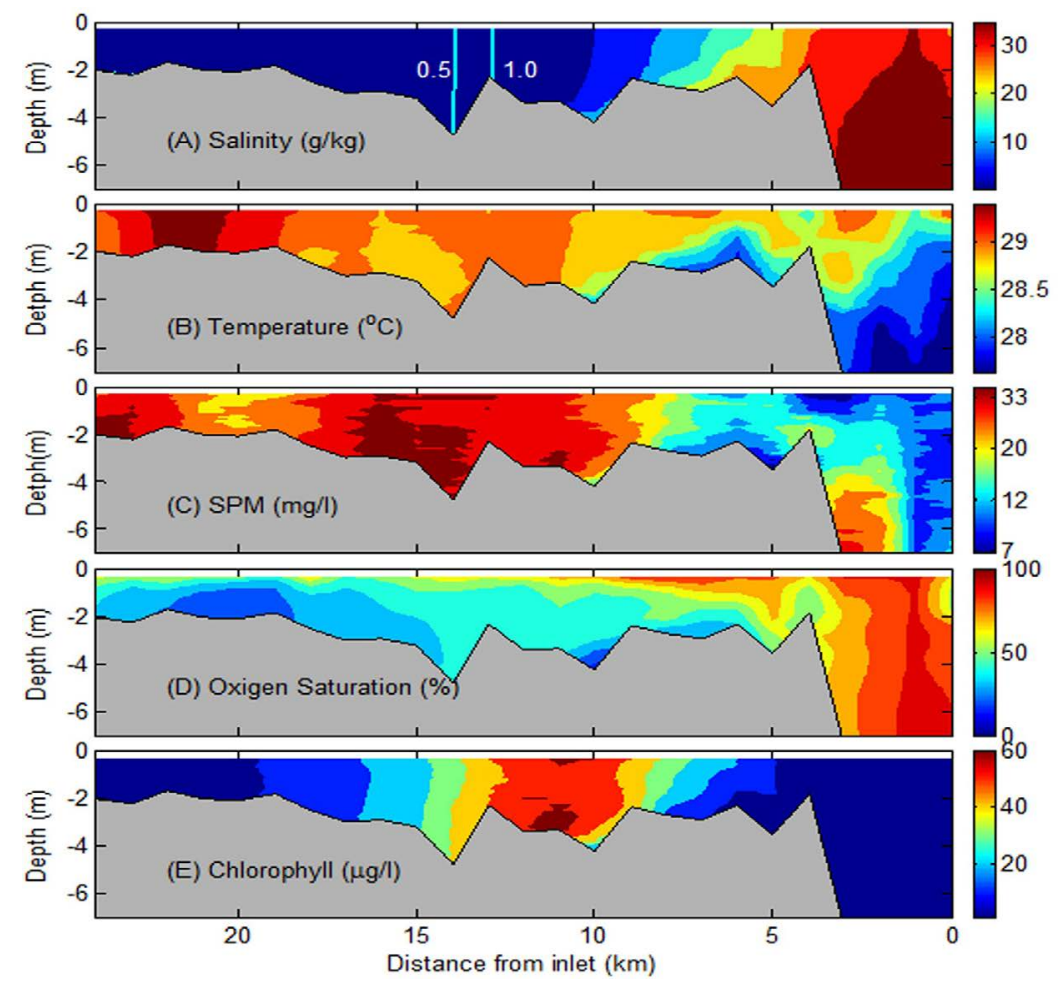

Figure 2. Field distributions of (a) salinity $\left(\mathrm{g} / \mathrm{kg}\right.$ ), (b) temperature $\left({ }^{\circ} \mathrm{C}\right),(\mathrm{d})$ suspended particulate matter $(\mathrm{SPM}, \mathrm{mg} / \mathrm{l}),(\mathrm{d})$ dissolved oxygen saturation (\%), and (e) chlorophyll $(\mu \mathrm{g} / \mathrm{l})$ along the Capibaribe Estuary on October 11 $1^{\text {th }}, 2013$. 


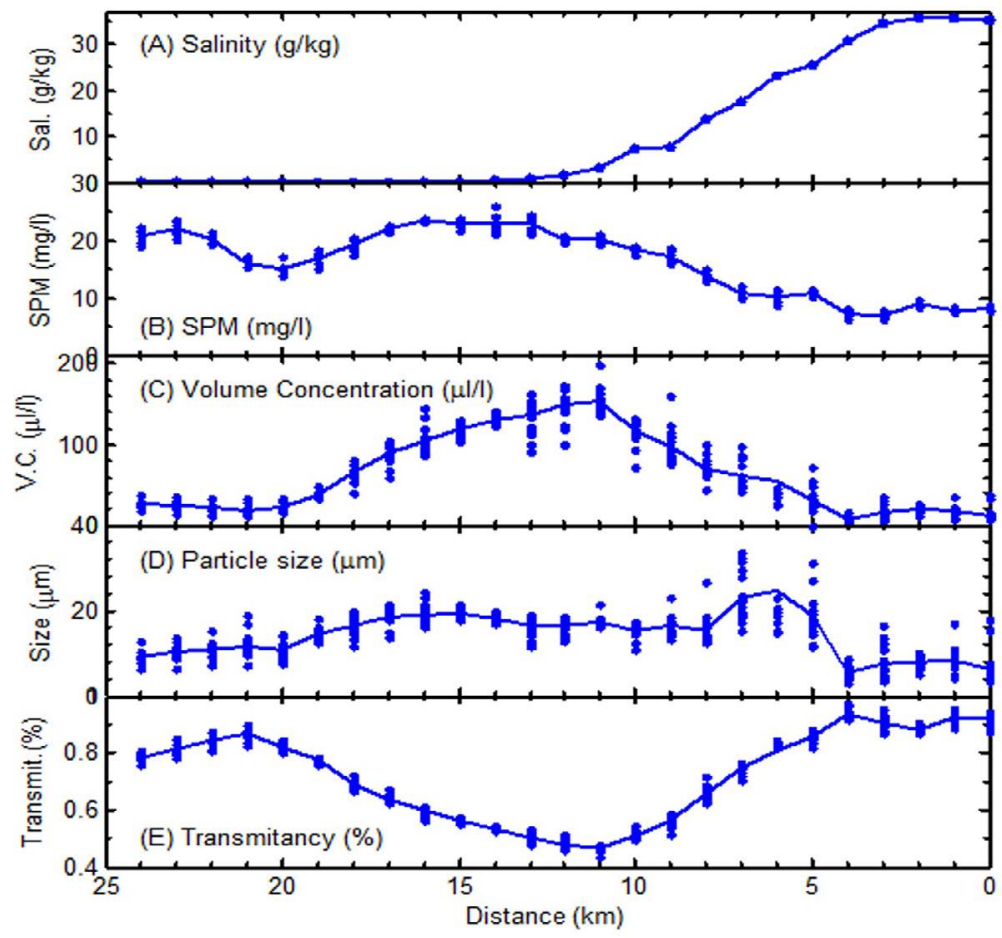

Figure 3. Longitudinal distribution of (a) salinity (g/kg), (b) suspended particulate matter (mg/l), (c) particle volume concentration (V.C., $\mu \mathrm{g} / \mathrm{l})$, (d) mean particle size $(\mu \mathrm{m})$ and (e) transmitancy $(\%)$ in the Capibaribe Estuary on October $11^{\text {th }}, 2013$.

continues to record all the time at $3 \mathrm{~s}$ intervals, but in this case the results were quite disappointing since apparently it lost its calibration rapidly. Its data were, however, highly valuable in the present case as they allowed the better visualization of the ETM, thus differentiating the different turbidity peaks recorded by the CTD.

There are several interesting implications of the presence of an ETM in an estuary, as described at the beginning of the note. The observation of the ETM in the Capibaribe estuary suggests that many other small and relatively shallow estuaries in the Brazilian NE region may also present this feature. Its presence clearly indicates a high trapping efficiency (DYER, 1995), and this is particularly relevant for the Capibaribe Estuary which receives the waste water of millions of people who live in its hinterland. Thus, in view of the fact that most of the waste water products will be associated with SPM, the Capibaribe estuary will work also as a concentrator of materials besides its role of filter of riverborne materials. The ETM in the Capibaribe estuary is not always present, as may be seen from our other surveys (without LISST). The one shown here was recorded after a long period without river discharge peaks and under neap tide conditions. These earlier results call for further investigation, in the Capibaribe and other systems. The questions which arise from this first approach are: (1) what are the mechanisms which allow the ETM formation? (2) what are the processes which maintain it? and (3) what is its role in the estuary in the trapping of material?

\section{REFERENCES}

ALLEN, G.P.; SALOMON, J.C.; BASSAULLET,P.; DU PENHOTA, Y.; DE GRANDPRÉ, C. Effects of tides on mixing and suspended sediment transport in macrotidal estuaries. Sediment. Geol., v. 26, p. 69-90, 1980.

ASP, N. E.; SCHETTINI, C. A. F.; SIEGLE, E.; SILVA, M. S.; BRITO, R. N. R. The dynamics of a friccionally-dominated amazonian estuary. Braz. J. Oceanogr., v. 60, n. 3, p. 391-403, 2012.

BRUNK, B. K.; JIRKA, G. H.; LION, L. W. Effects of salinity changes and the formation of dissolved organic coatings on the sorption of phenanthrene: implications for pollutant trapping in estuaries. Environ. Sci. Technol., v. 31, n. 1, p.119-125, 1996.

BURCHARD, H.; BAUMERT, H. The formation of estuarine turbidity maxima due to density effects in the salt wedge. A hydrodynamic process study. J. Phys. Oceanogr., v. 28, n. 2, 309-321, 1998.

CRUMP, B. C.; BAROSS, J. A. Particle-attached bacteria and heterotrophic plankton associated with the Columbia River turbidity maxima. Mar. Ecol. Prog. Ser., v. 138, p. 265-273, 1996.

D’AQUINO, C.; PEREIRA FILHO, J.; SCHETTINI, C. A. F. Fluvial modulation of hydrodynamics and salt transport in a highly stratified estuary. Braz. J. Oceanogr., v. 58, n. 2, p. 165-175, 2010.

DYER, K. R. Fine sediment particle transport in estuaries. In: DRONKERS, J.; VAN LEUSSEN, W. (Ed.). Physical Processes in Estuaries. Berlin: Springer-Verlag, 1988. p. 427-445. 
DYER, K. R. Sediment transport processes in estuaries. In: PERILLO, G. M. E. (Ed.). Geomorphology and Sedimentology of Estuaries: Developments in Sedimentology. New York: Elsevier Science, 1995. p. 423-449.

GELFENBAUM, G. Suspended-sediment response to semidiurnal and fortnightly tidal variations in a mesotidal estuary: Columbia river, U.S.A. Mar. Geol., v. 52, n. 1/2, p. 39-57, 1983.

GEYER, W. R. The importance of suppression of turbulence by stratification on the estuarine turbidity maximum. Estuaries, v. 16, n. 1, p. 113-125, 1993.

GRABEMANN, I.; UNCLES, R. J.; KRAUSE, G.; STEPHENS, J. A. Behavior of turbidity maxima in the Tamar (U.K.) and Weser (F.R.G.) estuaries. Estuar. Coast. Shelf Sci., v. 45, n. 2, 235-246, 1997.

JAY, D. J.; MUSIAK, J. D. Particle trapping in estuarine tidal flows. J. Geophys. Res., v. 99, n. C10, p. 20445-20461, 1994.

KISTNER, D. A.; PETTIGREW, N. R. A variable tubidity maximum in the Kennebec estuary, Maine. Estuaries, v. 24, n. 5, p. 680-687, 2001.

MANTOVANELLI,A.; MARONE, E.; SILVA, E. T.; LAUTERT, L.F.; KLINGENFUSS, M. S.; PRATA JUNIOR, V. P.; NOERNBERG, M. A.; KNOPPERS, B. A.; ANGULO, R. J. Combined tidal velocity and duration asymmetries as a determinant of water transport and residual flow in Paranaguá Bay estuary. Estuar. Coast. Shelf Sci., v. 59, n. 4, p. 523-537, 2004.

MORGAN, C. A.; CORDELL, J. R.; SIMENSTAD, C. A. Sink or swim? Copepod population maintenance in the Columbia River estuarine turbidity-maxima region. Mar. Biol., v. 129, n. 2, p. 309317, 1997.

OLIVEIRA, T. S.; BARCELlOS, R. L.; SCHETTINI, C. A. F.; CAMARGO, P. B. Processo sedimentar atual e distribuição da matéria orgânica em um complexo estuarino tropical, Recife, PE, Brasil. J. Integr. Coast. Zone Manag., v. 14, n. 3, p. 399-411, 2014.

PEREIRA-FILHO, J.; SCHETTINI, C. A. F.; RÖRIG, L.; SIEGLE, E. Intratidal variation and net transport of dissolved inorganic nutrients, POC and chlorophyll a in the Camboriú River estuary, Brazil. Estuar. Coast. Shelf Sci., v. 53, p. 249-257, 2001.
POSTMA, H. Sediment transport and sedimentation in the estuarine environment. In: LAUFF, G. H. (Ed.) Estuaries. Washington: American Association for the Advancement of Science, 1967. p. 158-179.

RIBEIRO, C. G.; KOLM, H. E.; MACHADO, E. C. Short-term variability of bacterioplankton in the maximum turbidity zone in the Paranaguá Bay, Southern Brazil, and its relationship with environmental variables. Braz. Arch. Biol. Technol., v. 54, n. 5, p. 947-955, 2011.

SCHETTINI, C. A. F.; MIRANDA, L. B. Circulation and suspended particulate matter transport in a tidally dominated estuary: caravelas estuary, Bahia, Brazil. Braz. J. Oceanogr., v. 58, n. 1, p.1-11, 2010.

SCHETTINI, C. A. F.; TOLDO JÚNIOR, E. E. Fine sediment transport modes in the Itajaí-açu estuary, Southern Brazil. J. Coast. Res., v. 39 , n. 1, p. 515-519, 2006.

SCHETTINI, C. A. F.; PEREIRA M. D.; SIEGLE, E.; MIRANDA, L. B.; SILVA, M. P. Residual fluxes of suspended sediment in a tidally dominated tropical estuary. Cont. Shelf Res., v. 70, p. 2735, 2013.

SCHETTINI, C. A. F.; RICKLEFS, K.; TRUCCOLO, E. C.; GOLBIG, V. Synoptic hydrography of a highly stratified estuary. Ocean Dyn., v. 56, n. 3, p. 308-319, 2006.

SCHUBEL, J. R. Turbidity maximum of the northern Chesapeake Bay. Science, v. 161, n. 3845, p. 1013-1015, 1968.

UNCLES, R. J.; BARTON, M. L.; STEPHENS, J. A. Seasonal variability of fine-sediment concentrations in the turbidity maximum region of the Tamar Estuary. Estuar. Coast. Shelf Sci., v. 38, n. 1, p.19-39, 1994.

WOLANSKI, E.; KING, B.; GALLOWAY, D. Dynamics of turbidity maxima in the Fly River estuary, Papua New Guinea. Estuar. Coast. Shelf Sci., v. 40, n. 3, p. 321-337, 1995.

YU, Q.; WANG, Y.; GAO, J.; GAO, S.; FLEMMING, B. Turbidity maximum formation in a well-mixed macrotidal estuary: the role of tidal pumping. J. Geophys. Res., v. 119, n. 11, p. 7705-7724, 2014. 
